\title{
FRIT FLY (OSCINIS FRIT) IN WINTER WHEAT.
}

\author{
By F. R. PETHERBRIDGE. \\ (School of Agriculture, Cambridge.)
}

IN a previous article ${ }^{1}$ the writer has given examples of bad attacks of this fly on winter wheat following leys containing either rye grass or Italian rye grass.

The following experiments show that this is due to the fact that the autumn brood of flies lay their eggs on the grass, and that the larvae feed on the shoots, and after the grass is ploughed in, they eventually migrate to the young wheat plants.

In 1917 a bad attack of frit fly was noticed on one part of a field of wheat on the University Farm, whereas the other part of the field was practically free from attack.

The following shows the differences in the previous treatment of these two pieces of wheat.

Part A. Badly attacked by Frit Fly.

Crop in 1916--Italian rye grass and red clover. Ploughed November 3rd, 1916.

Little Joss sown November 10th, 1916.

Part B. No Frit Fly attack.

Crop in 1916-Red Clover.

Ploughed October 10th, 1916.

Little Joss sown October 23rd, 1916.

As a result of this and other observations, an experiment was arranged to see if the ploughing in of the rye grass before autumn would prevent an attack of frit fly.

In 1917 a piece of trefoil and Italian rye grass was divided into three plots.

Plot $A$ was ploughed on July 12 th, cross ploughed on July 14th.

Cultivated from August 26th onwards.

Harrowed on September 26th.

Drilled on October 3rd.

1 Loc, cit. vol. Iv, Nọs, I and 2, September 1917. 
Plot B Fed off by sheep.

Ploughed on October 1st, then harrowed, and drilled on October 3rd.

Plot C Fed off by sheep.

Ploughed on November 1st, then harrowed, and drilled on November 3rd.

The results observed were as follows:

Plot A. Although I made several careful searches I did not find a single plant attacked by frit fly.

Plot B. Fairly bad attack of frit fly. About 10 per cent. of the plants attacked.

Plot $C$. This plot was damaged by birds, so that it was difficult to estimate the amount of damage, but many frit larvae were found.

This experiment was repeated in 1919-1920 with a view to determining when the frit fly larvae migrate from the rye grass into the wheat.

Before ploughing in the autumn the Italian rye grass was examined and found to be very badly attacked by frit fly larvae, which were feeding on the young shoots. The intensity of the attack was probably increased by the ploughing up of over 90 per cent. of the rye grass in summer and thus leaving a much smaller amount of grass in which the flies could lay eggs.

Plot A. Crop in 1919--Italian rye grass and trefoil.

Ploughed July 25th.

Wheat drilled October 30th.

Very few frit larvae found in wheat. A few also found in Italian rye grass plants not ploughed under. A few plants attacked by wheat bulb fly.

Plot B. Crop in 1919--Italian rye grass and trefoil.

Ploughed November 7th.

Drilled November 20th.

About 25 per cent. of the plants attacked by frit laryue. A few plants attacked by wheat bulb fly.

Plot C. Crop in 1919-Rye and vetches.

Folded with sheep.

Wheat drilled in July, 1919.

A few frit fly larvae found. A few wheat bulb fly larvae attacking wheat and couch (Agropyrum repens). 
Plot D. Crop in 1919-Mangolds and cabbages. Wheat drilled November 20th.

No frit fly larvae found. Fairly bad attacks of wheat bulb fly in patches.

Plot F. Crop in 1919-Mangolds, swedes and turnips. Wheat drilled December 18th and 19th.

No frit fly larvae found. Fairly bad attacks of wheat bulb fly in patches.

In the above experiments the only loss of crop from frit fly was after Italian rye grass ploughed in during the autumn. The ploughing in of the rya grass before harvest (i.e. bastard fallowing) prevented a loss of wheat from the attacks of frit $\mathrm{fly}$.

On Plot B tufts of buried rye grass were dug up during the winter and examined for frit fly larvae at intervals of about a month.

On January 7 th a large number of frit fly larvae were present in the rye grass, and many of the shoots were not decayed.

On February 6th a few frit larvae were found to be attacking the wheat plants, but large numbers were still present on the rye grass.

Throughout February and March the attack on the wheat gradually became worse, whereas the number of larvae in the rye grass gradually became fewer. April 7th was the last date on which frit fly larvae were found in the buried rye grass. By this date much of the rye grass was decayed, but a few shoots seemed to be suitable as food for the larvae.

\section{Pot Experiments.}

These experiments were carried out in 5 inch pots in the laboratory. No. of

Pot

Procedure

Remarks

1 Tuft of rye grass (dug up from Plot B) containing frit fly larvae buried in soil in pot. Wheat sown February 16 th

29 frit fly larvae from buried rye grass placed near seedling wheat plants on February 6 th

3 Small pieces of rye grass containing 6 frit $\mathrm{Hy}$ larvae buried near seedling wheat plants on February 2nd

48 frit tly larvae from buried rye grass placed near seedling wheat plants on February 9th

57 trit fly larvae from buried rye grass placed near seedling wheat plants on February 16 th

64 frit fly larvae from buried rye grass placed near seedling wheat plants on February 2 nd

2 more added on March 3rd

1 more added on March 25th

2 plants attacked on March 16th

9 plants attacked on April 17th

3 plants attacked on March 26th

3 plants attacked on March 26th

2 plants attacked on March 3rd

3 plants attacked on March 26th

1 plant attacked on March 26th

3 plants attacked on April 1st

Examination of the attacked plants showed that the damage in all cases was 'due to frit fly larvae 
No flies hatehed out from these pots. An examination of the attacked plants showed that some of the larvae died before pupation. The single pupa which was found was parasitised.

Of the cases of winter wheat attacked by "frit fly" which I have examined during the last few years, nearly all have been after a ley containing one of the rye grasses ploughed up during the autumn.

On a farm in Norfolk only one field of wheat alter rye zrass had escaped. This was ploughed up in the middle of Auzust. whereas the fields which were attacked were ploughed up much later.

In Cambridgeshire I found a piece of wheat slightly attacked, following a crop of turnips, but in this case the land was very foul with couch (Agropyrum repens) and other grass weeds. so that it is quite probable that the egess were laid on these.

The only other exception was after a crop of white clover, where it is probable that wrasses wre present with the clurer, although not sown.

I have never seen any appreciable reduction in (rop from an attach after potatoes, beans, corn or fallow, but it seems probable that if after either of these the land was covered with grass weed during the early autumn, the wheat following might be attacked. I have often seen wheat after the above crops free from attactis when neighbouring fields were attacked.

The damage done by the frit maggot serems to be more on a loose tilth than on a compact tilth. In the former case a larger percentage of plants die, probably because they do not tiller so quickly as on firmer soils. Fields in good condition suffer less thin those in poor heart probably for a similar reason.

These experiments and observations prove that the frit fly larvae present in the rye wrasses are capabie of migrating to and damaging wheat plants after the crass is plowghed in.

They also show that an attack of frit fly on winter wheat following rye grass may be avoided by bastard fallowing. Wheat after a bastard fallow, however, is very liable to a bad attack of wheat bulb fly (Leptohylemia courdata), although in the alowe experiments this pest did very little damage after this method of procedure. 